\title{
Las proyecciones de cine militante clandestinas al interior de las organizaciones políticas 1968-1973. La experiencia formativa
}

Carolina Andelique

Facultad de Humanidades y Ciencias, UNL

«El film es el pretexto para el diálogo, para la búsqueda y el encuentro de voluntades» Hacia un Tercer Cine. Cine Liberación I969.

\section{Resumen}

Este trabajo aborda el desarrollo de las proyecciones clandestinas o alternativas de cine militantes realizadas al interior de diferentes organizaciones políticas entre los años I968 y 1973 en la ciudad de Santa Fe. En el contexto de censura y persecución instaurado por la dictadura militar de 1966, la realización de proyecciones de cine militante por parte de organizaciones políticas se constituye en un acto mismo de militancia para los asistentes, quienes ven en éstas una forma más de aportar a la discusión política y social en la lucha por la liberación.

A partir de la pregunta sobre qué vínculo existía entre los distintos grupos realizadores de cine militante y las organizaciones políticas a mediados de los años sesenta,

Palabras clave:

Cine Militante, circuitos clandestinos o alternativos de proyecciones, organizaciones políticas, grupos de realizadores. 
será posible comenzar a pensar cómo las proyecciones de cine al interior de las organizaciones eran en sí un acto formativo para los militantes, y qué características asumía este tipo de proyecciones en los diferentes espacios en que se realizaba y a partir de la diversidad de público que podía concurrir.

Los testimonios de ex militantes que participaron como asistentes u organizadores de este tipo de proyección clandestina o alternativa serán insumo de este trabajo, permitiéndonos vislumbrar el valor que como acto militante tenía dicha participación.

\section{Abstract}

This work approaches the development of clandestine or alternative film screenings of militant cinema produced within different political organizations between 1968-1973 in Santa Fe city. In the context of censorship and persecution by the 1966 military dictatorship, film screenings of militant cinema by political organizations becomes an act of militancy for the attendees, who find in them a way to contribute to the political and social discussion in the fight for freedom

Starting from researching into the link between different groups of militant cinema filmmakers and the political organizations in the mid sixties, it will be possible to start thinking about how film screenings in this organizations constituted a formative act in itself for the militants, and about the characteristics of this kind of film screenings in the different spaces where they took place, beginning with the diversity of the possible audience.

The testimonies of former militants who participated as assistants or organizers of this kind of clandestine or alternative film screening will be an input to this work, allowing us to understand the value of such participation as a militant act.

\section{Keywords:}

Militant cinema, clandestine or alternative film screening circuits, political organizations, filmmakers groups. 